\title{
Inspiracje sztuką i kulturą Podhala w powojennej galanterii i biżuterii polskiej
}

DOI: https://doi.org/10.21697/an.9370

MICHAt MYŚLIŃSKI

INSTYTUT SZTUKI PAN

ORCID 0000-0001-5977-2142

Zainteresowanie sztuką Podhala, tj. stosowanymi w tzw. ludowej twórczości artystycznej tego regionu ornamentami i ich genezą, motywami ikonograficznymi w dziełach malarstwa i rzeźby, formą dzieł architektury, a przede wszystkim realizacjami z zakresu snycerstwa, kowalstwa i innych rzemiosł, w sposób szczególny zauważalne było już od przełomu XIX i XX w. Wskazać tu można zarówno nurt polegający na niekiedy dość swobodnym przekształcaniu lokalnych motywów i tworzeniu dzieł de facto tylko częściowo osadzonych w lokalnej tradycji, jak i nurt naukowy, oparty na inwentaryzacji licznych przedmiotów i rzetelnej analizie sztuki regionu. Nie wnikając absolutnie w genezę obu tych postaw oraz efektów, jakie przyniosły one w sztuce polskiej pierwszej połowy XX w., wspomnieć jednak należy, iż uwagę na kulturę artystyczną i materialną Podhala - zwaną wówczas ogólnie sztuką „domową" - zwrócono już w 1894 r., m.in. rekonstruując podczas Wystawy Krajowej we Lwowie drewniane chałupy góralskie. Natomiast istotnymi opracowaniami z tego czasu, będącymi niejako podstawą dalszych badań, stały się publikacje Stanisława Witkiewicza z 1899 r. oraz Władysława Matlakowskiego z 1901 r., z których w tej drugiej zawarto bardzo liczne przedstawienia podhalańskich dzieł sztuki i przedmiotów użytku codziennego' (il. 1, 2, 3).

Nieco później szczególne zainteresowanie tą sferą sztuki ludowej rozwijali polscy artyści skupieni w stowarzyszeniach Polska Sztuka Stosowana oraz „Kilim”, Towarzystwie Artystów Polskich „Sztuka”, później zaś w Warsztatach Krakowskich, czego wymownym znakiem - i wielkim sukcesem - okazała się polska ekspozycja na paryskiej Międzynarodowej Wystawie

\footnotetext{
1 Literatura dotycząca tzw. stylu zakopiańskiego jest niezwykle obfita i wielowątkowa, zatem przytaczanie jej tutaj w całości przekroczyłoby przyjęte powszechnie ramy przywoływania podstaw aktualnego stanu wiedzy i badań; niemniej należy wskazać przede wszystkim pozycje o charakterze źródłowym: S. Witkiewicz, Styl zakopiański, w: Sztuka i krytyka u nas (1884-1898), Lwów - Warszawa - Poznań 1899, s. 619-667; W. Matlakowski, Zdobienie i sprzęt ludu polskiego na Podhalu. Zarysy życia ludowego, Warszawa 1901; Listy o stylu zakopiańskim 1892-1912. Wokół Stanisława Witkiewicza, opr. M. Olszaniecka, A. Micińska, wstęp, kom., opr. M. Jagiełło, Kraków 1979; natomiast z najnowszych opracowań, cennych ze względu na zawartość bogatego wyboru bibliografii tematu, zob. J. Hübner-Wojciechowska, Sztuka Skalnego Podhala. Przewodnik dla kolekcjonerów, Warszawa 2019.
} 


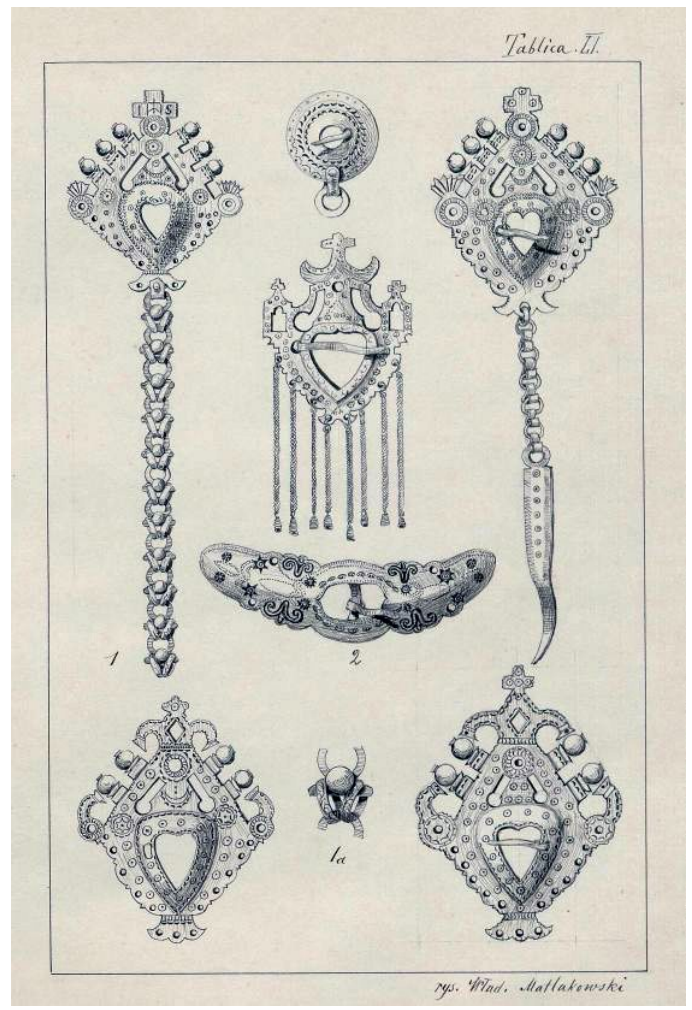

1. Spinki i klamry góralskie.

Fot. wg: W. Matlakowski, Zdobienie i sprzęt ludu polskiego na Podhalu. Zarysy życia ludowego, Warszawa 1901, tabl. LI

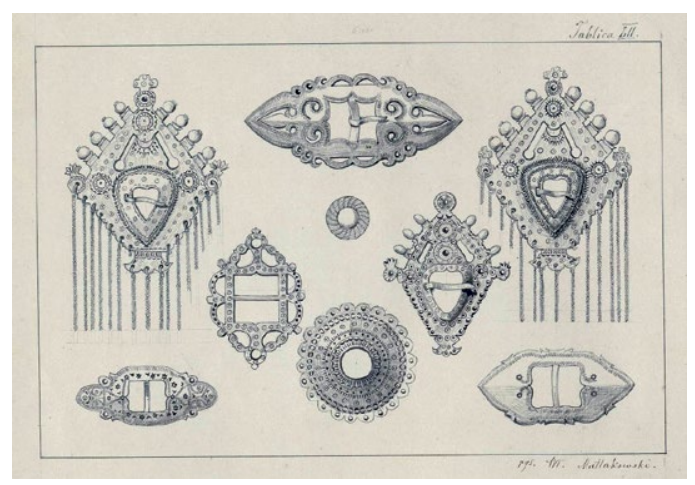

3. Spinki i klamry góralskie.

Fot. wg: W. Matlakowski, Zdobienie i sprzęt ludu polskiego na Podhalu. Zarysy życia ludowego, Warszawa 1901, tabl. LIII

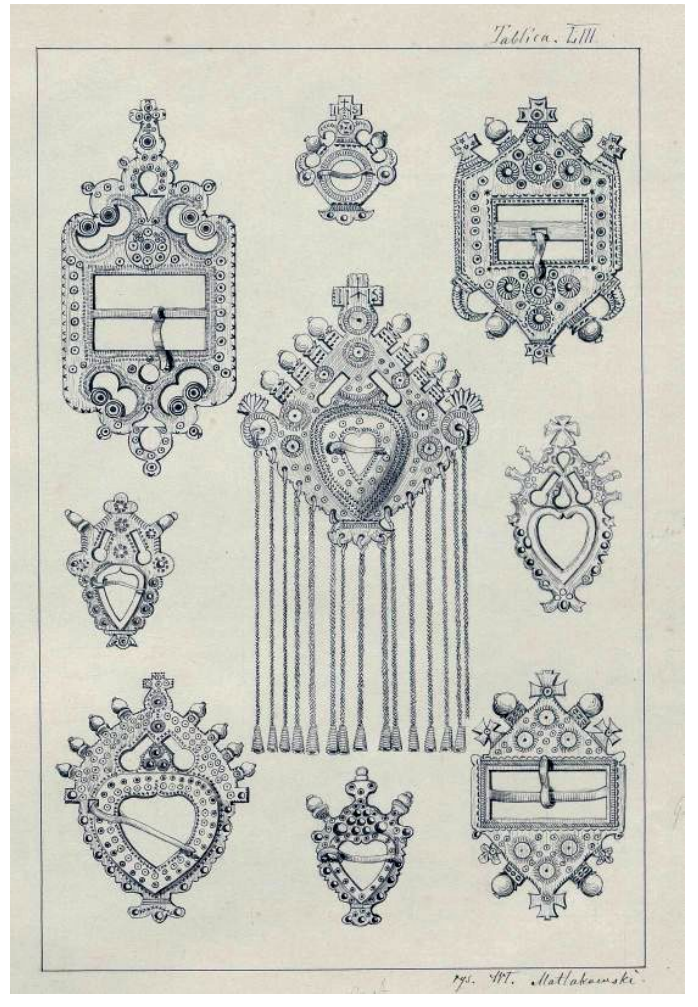

2. Spinki i klamry góralskie.

Fot. wg: W. Matlakowski, Zdobienie i sprzęt ludu polskiego na Podhalu. Zarysy życia ludowego, Warszawa 1901, tabl. LII

Sztuk Dekoracyjnych i Nowoczesnego Przemysłu w 1925 r. ${ }^{2}$ Warto przy tym podkreślić, że zainteresowanie sztuką podhalańską, określaną różnymi terminami, z których bodajże najpopularniejszy to „zakopiańszczyzna", wynikało nie tylko z fascynacji specyfiką i odmiennością jej form, ale przede wszystkim $\mathrm{z}$ bardzo intensywnych ideowo-artystycznych spekulacji i poszukiwań tzw. sztuki narodowej i rodzimej. W tym właśnie głównym kontekście kulturę artystyczną Podhala, jako wciąż realnie żywą i kultywowaną na bieżąco, przywoływano w Warsztatach Krakowskich, gdzie stanowiła ona przede wszystkim punkt wyjścia do nowoczesnych rozwiązań formalnych i technologicznych w zakresie

2 Swoiste podsumowanie badań nad dziełami sztuki polskiej, eksponowanymi na wystawie paryskiej zawiera publikacja referatów wygłoszonych na sesji zorganizowanej w 2005 r. Wystawa paryska 1925. Materiały z sesji naukowej Instytutu Sztuki PAN, Warszawa 16-17 listopada 2005 roku, red. J. Sosnowska, Warszawa 2007. 
tkactwa, zabawkarstwa, batiku na tkaninach i drewnie oraz tzw. metaloplastyki ${ }^{3}$.

Ten specyficzny kontekst sztuki podhalańskiej, często zresztą stawiający ją w pewnej uprzywilejowanej pozycji wobec kultury materialnej i artystycznej innych polskich regionów, ale tak naprawdę wynikający z interpretacji, nie zaś jej istotnie naturalnych „rodzimych” lub „polskich” form, został niejako przeniesiony w lata powojenne - i w pełni świadomie, z przyczyn politycznych, przez decydentów odtrącony. Szczególnym dowodem dokonanej gwałtownie zmiany było niemal całkowite zarzucenie wykonywania, noszenia i propagowania tzw. krzyżyka niespodzianego, który jeszcze do wybuchu II wojny światowej powszechnie widniał na miejscowych zabytkach architektury, pamiątkowych głazach i np. odznakach pułków strzelców podhalańskich. W efekcie pozwoliło to w czasach już powojennych góralską kulturę materialną i sztukę traktować niemal wyłącznie jako rezerwuar gotowych do wykorzystania form i ornamentów, bez ich szczególnych interpretacji politycznych. Tak sformułowaną rolę nośnika tradycji podhalańskiej i tzw. stylu zakopiańskiego pełniła powołana w czerwcu 1949 r. Centrala Przemysłu Ludowego i Artystycznego, zwana popularnie Cepelią, kierowana przez Zofię Szydłowską4. Dość szybko, bo już w latach 1945-1949 z inicjatywy lokalnych twórców (także ludowych), plastyków, a także ludzi prowadzących badania naukowe powoływano na Podhalu spółdzielnie, m.in. w Zakopanem (Zakopiańskie Warsztaty Wzorcowe), Nowym Targu (Podhalańska Spółdzielnia Tkacko-Trykotarska)

3 I. Huml, Warsztaty Krakowskie, Wrocław-WarszawaKraków-Gdańsk 1973 (reedycja tekstu: M. Dziedzic, I. Huml, A. Myczkowska, A. Pleciak, A. Szwaja, Warsztaty Krakowskie 1913-1926, Kraków 2009).

4 P. Korduba, Ludowość na sprzedaż. Towarzystwo Popierania Przemysłu Ludowego, Cepelia, Instytut Wzornictwa Przemysłowego, Kraków 2013.

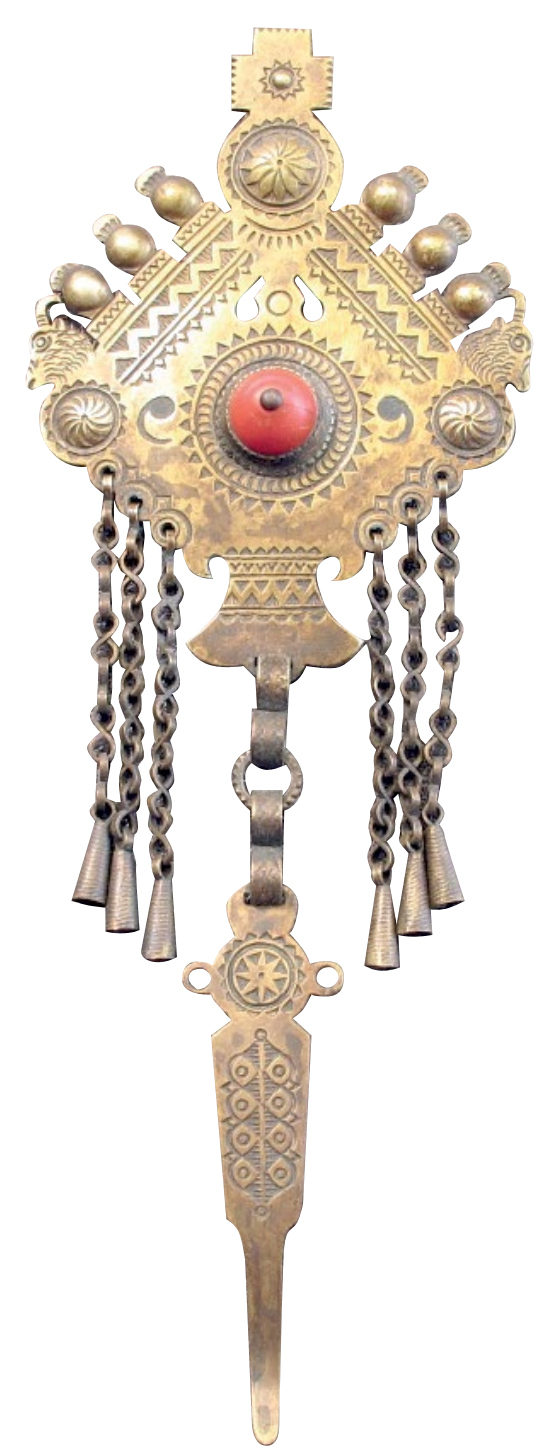

4. Spinka góralska ozdobna, blacha mosiężna wycinana, tłoczona, puncowana, koral naturalny (?), lata 40.-50. XX w., wł. prywatna. Fot. udostępniona

i Makowie Podhalańskim (HafciarskoKrawiecka Spółdzielnia Pracy „Makowianka"), w ramach których podjęto przede wszystkim produkcję regionalnej odzieży (kierpce, serdaki, rękawice), tkanin (kilimy), galanteryjnych wyrobów skórzanych (torby, portfele, zakładki do książek), sprzętów drewnianych (szafki, łyżniki, sztućce, pudełka, okładki pamiętników) itp. W spółdzielniach funkcjonowały również niewielkie działy metalowe, produkujące głównie drobną metalową galanterię i elementy 


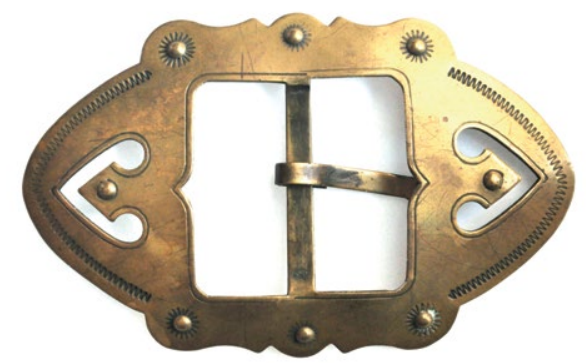

5. Klamra ozdobna góralska do pasa, blacha mosiężna wycinana, tłoczona, puncowana, lata 6o.-70. XX w., wł. prywatna. Fot. udostępniona

stroju ludowego oraz tzw. pamiątki (sprzączki i cekiny do kierpców i pasów, spinki do koszul, okucia ciupag, fajek „zbójnickich" itp.) $)^{5}$. Oprócz wspomnianych spółdzielni funkcjonowały dość liczne, oferujące podobne wyroby pamiątkarskie niewielkie wytwórnie prywatne (od przełomu lat 40. i 50. XX w. niekiedy przejmowane przez państwo), a produkcję tego asortymentu podejmowały inne spółdzielnie, np. krakowska Spółdzielnia Pracy Wytwórców Rękodzieła Artystycznego „Milenium”. Trzeba przy tym podkreślić, że podhalańskie spółdzielnie cepeliowskie i zakłady prywatne nie prowadziły masowej produkcji biżuterii, bowiem zdecydowanie inny był ich profil wytwórczy, a ponadto ich głównym zadaniem było kultywowanie i ochrona miejscowego, specyficznego rzemiosła. Stąd w zakresie galanterii metalowej produkowano przede wszystkim spinki męskich koszul, adresowane do dwóch grup odbiorców - pierwszą z nich byli sami górale, dla których spinki były tradycyjnym lecz wciąż używanym elementem stroju regionalnego, drugą zaś turyści,

5 R. Gmurczyk, Organizacja cepeliowska w latach 1949-2014. Fakty i ludzie, Warszawa 2014, s. 180-187, 193-196.

6 Tamże, s. 240-241.

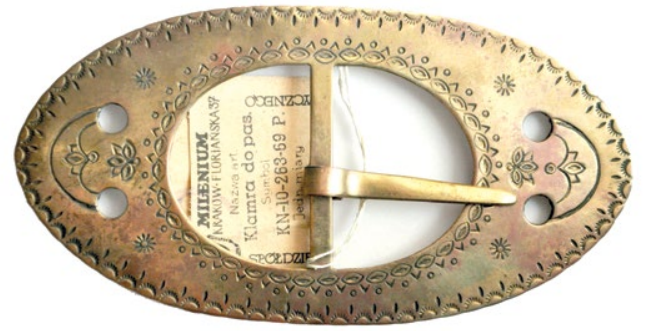

6. Klamra ozdobna góralska do pasa, blacha mosiężna wycinana, tłoczona, puncowana, wyk. Spółdzielnia Milenium, Kraków, 1969, wł. prywatna. Fot. udostępniona

traktujący je wyłącznie jako wyrób pamiątkarski (il. 4). O ile forma i funkcja spinek góralskich pozostawała zasadniczo niezmienna, choć mogły być one bardzo ozdobne lub nieco skromniejsze w kształcie i materiale, to nieco inaczej traktowano inne wyroby galanteryjne. Przywołać tu należy np. ozdobne sprzączki (klamerki), które przede wszystkim stanowiły doposażenie skórzanych pasów męskich spodni lub pasów damskich torebek (il. 5-6), ale jednocześnie mogły stanowić swoisty prefabrykat do wyrobu biżuterii, bowiem mocno wydłużona, owalna forma sprzączki niemal idealnie nadawała się do wykonania z niej np. podłużnej broszki lub spinki do włosów (il. 7, 9). W zbiorach prywatnych znajdują się przykłady takich broszek i spinek o formie przypominającej sprzączkę, jak i nieliczne bransolety, formowane z dwóch lub niekiedy nawet trzech łukowo wygiętych i łączonych kolistymi ogniwkami klamerek, z których uprzednio wymontowano szpilę. W podobny sposób wyginano w obręcz bransolet niewielkie, pamiątkowe noże do papieru, wzorowane na tzw. kozikach zbójnickich (il. 8). Trudno jednak jednoznacznie stwierdzić, czy biżuteria tego rodzaju została wytworzona niejako wtórnie, tzn. wykonano ją według 


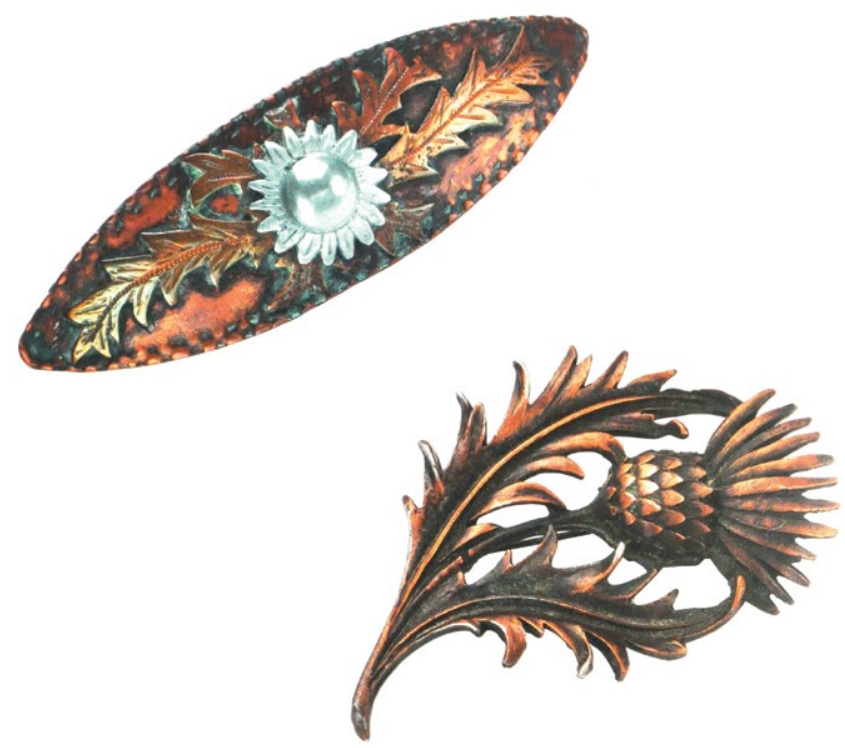

7. Spinka do włosów z kwiatem dziewięćsiłu i broszka z kwiatem ostu, blacha miedziana, wycinana, wytłaczana, odlew, lata 40.-50. XX w. Kolekcja Współczesnej Polskiej Sztuki Złotniczej M.M. Kwiatkiewicz. Fot. wg: Hand Made. Polska sztuka srebra lat 1945-1979, red. K. Nowakowska, Legnica 2020, s. 48-49

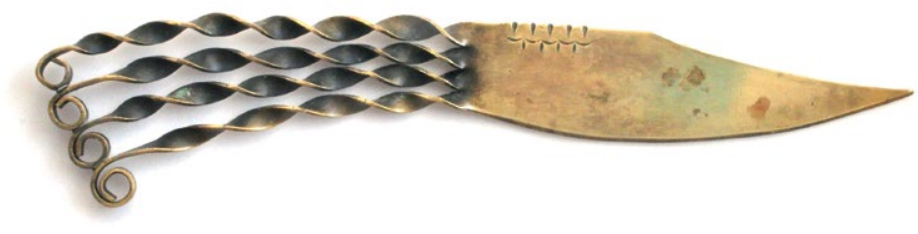

8. Nożyk do papieru, wzorowany na koziku góralskim, blacha mosiężna wycinana, skręcana, zwijana, tłoczona, lata 60.-70. XX w., wł. prywatna. Fot. udostępniona

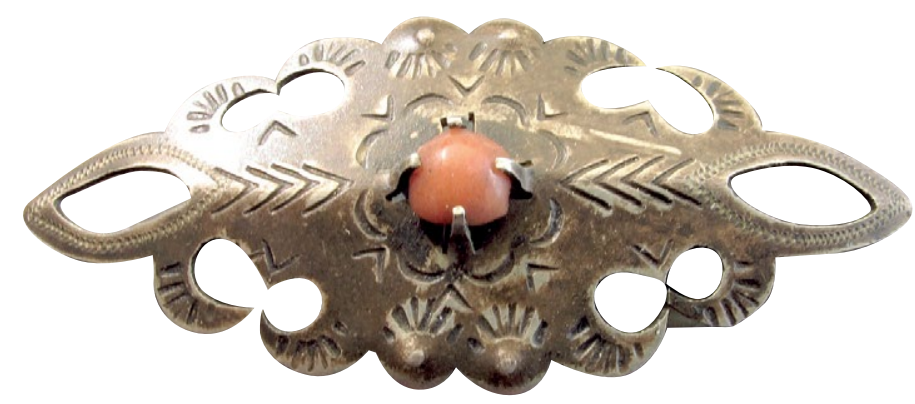

9. Broszka góralska ozdobna, blacha mosiężna wycinana, puncowana, koral naturalny (?), lata 40.-50. XX w., wł. prywatna. Fot. udostępniona indywidualnego pomysłu użytkowniczki, która jedynie przystosowała do niego zakupione sprzączki lub noże, czy też było to oryginalnym pomysłem podhalańskiego wytwórcy, który tym sposobem powiększał krąg odbiorców swojego asortymentu.

O ile wspomniane spółdzielnie cepeliowskie prowadziły produkcję, kultywując lokalną tradycję wzornictwa przedmiotów codziennego użytku i rozwijając ją w kierunku pewnego unowocześnienia, co zresztą było jedną z idei powołania Cepelii, to tego rodzaju ograniczenia nie wpływały na założenia Biura Nadzoru Estetyki Produkcji, powołanego w październiku 1945 r. pod nazwą Wydziału Wytwórczości Ministerstwa Kultury i Sztuki i kierowanego przez Wandę Telakowską7. Celem BNEP-u było stworzenie warunków dla produkcji przemysłowej, a następnie takie jej ukierunkowanie, by maksymalnie wykorzystać tradycję ludowej sztuki i kultury materialnej. Trzeba przy tym podkreślić, że nieco inaczej niż w przypadku początków działania Cepelii statut BNEP zakładał twórcze odwoływanie się do całości tradycyjnej sztuki polskiej - przede wszystkim uwaga nie została skupiona jedynie na kulturze ludowej, tj. wiejskiej, a poza tym zdecydowanie odrzucano jedynie „mechaniczne” kopiowanie oraz konserwatywne kontynuowanie wzornictwa. Dawało to zatem olbrzymie pole do nowatorskich interpretacji form, technologii, ikonografii, choć swobodę twórczą skutecznie ograniczały prozaiczne możliwości przemysłowe powojennej Polski, jak i oczekiwania odbiorców. W tym ostatnim przypadku swoistym probierzem nastrojów estetycznych były organizowane przez BNEP wystawy objazdowe

7 A. Kasprzak-Miler, Wpływ Biura Nadzoru Estetyki Produkcji na kształt polskiej biżuterii artystycznej, w: W kręgu sztuki przedmiotu. Studia ofiarowane Profesor Irenie Huml przez przyjaciół, kolegów i uczniów, red. M. Dłutek, współpr. A. Kostrzyńska-Miłosz, Warszawa 2011, s. 255-264. 


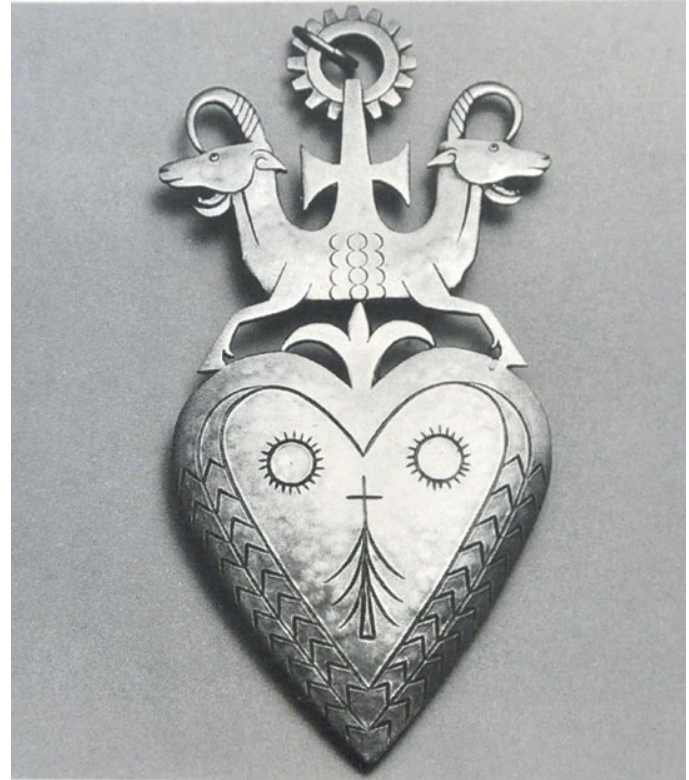

10. Wisior Dwa półkozły, stylizowany na spinkę góralską, blacha srebrna wycinana, kuta, grawerowana, proj. Henryk Grunwald, 19451955. Fot. wg: K. Nowakowska, Grunwald. Mistrz kompozycji w metalu, Legnica 1998, poz. 89

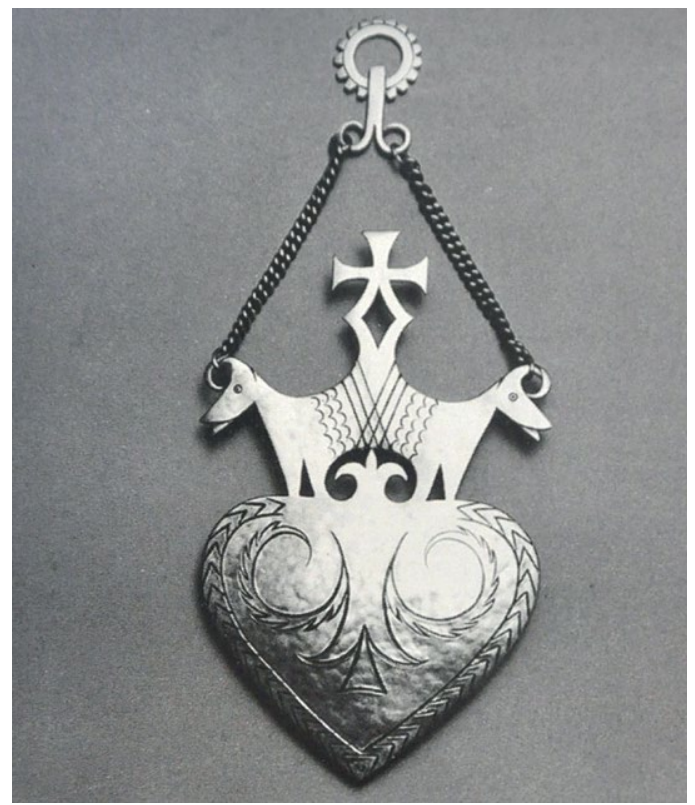

11. Wisior z motywem półkozłów i serca, stylizowany na spinkę góralską, blacha srebrna kuta, grawerowana, proj. Henryk Grunwald, pocz. lat 50. XX w. Fot. wg: K. Nowakowska, Grunwald. Mistrz kompozycji w metalu, Legnica 1998, poz. 87 z prezentowanymi wyrobami - tkaninami, meblami, ceramiką, szkłem itp., jak i po prostu popyt na przedmioty trafiające później do handlu. Trzeba przy tym pamiętać, że w BNEP wzornictwo biżuterii stanowiło jedynie niewielką część wszystkich podejmowanych działań, choć z pewnością bardzo efektowną. Istotnym w zakresie wzornictwa propagowanej wówczas biżuterii wydaje się fakt, że BNEP nie było „strażnikiem" stylu zakopiańskiego, a motywy nawiązujące do kultury duchowej oraz materialnej Podhala jedynie wpisywały się w nurt bardzo szeroko rozumianej inspiracji sztuką ludową. Dowodem takiego właśnie stosunku do sztuki Podhala są dwie serie wisiorów i broszko-wisiorów autorstwa Henryka Grunwalda, powstające już od drugiej połowy lat 40. XX w., lecz zdecydowanie nawiązujące w zakresie formy wprost do form sztuki użytkowej art déco"; pierwszą tworzą ażurowe wisiory stylizowane na spinki góralskie, drugą zaś broszko-wisiory i broszki z przedstawieniami zbójników, które można włączyć do szerszego nurtu ilustracji baśni i legend o Janosiku ${ }^{10}$. Wisiory mają zazwyczaj sercowaty kształt z krzyżykiem jako zwieńczeniem lub podwieszeniem, a uzupełniają je inne elementy kojarzące się z Podhalem, np. rogate kozice, grawerowane wyobrażenia słońca itp. (il. 10-11). Ten sam, nawiązujący do Podhala kontekst mają wyobrażenia tańczących lub skaczących zbójników, łatwych do rozpoznania dzięki specyficznemu strojowi, są oni bowiem odziani w wąskie spodnie $\mathrm{z}$ bardzo szerokim pasem

8 A. Kasprzak-Miler, A. Frąckiewicz,Polska biżuteria artystyczna z lat 1945-1950 ze zbiorów Muzeum Narodowego w Warszawie, Warszawa 1999.

9 Termin „wisior”, odnoszący się do ozdoby noszonej na łańcuchu zawieszonym na szyi, stosuję za: $M$. Gradowski, Dawne złotnictwo. Technika i terminologia, Warszawa 1984, s. 136-137.

10 K. Nowakowska, Grunwald. Mistrz kompozycji w metalu, Legnica 1998, poz. 86-91; 95-98. 


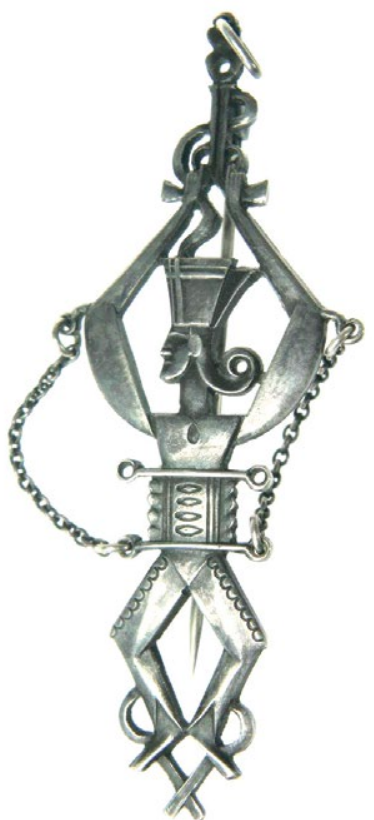

12. Broszko-wisior Tańczący zbójnik, blacha srebrna wycinana, kuta, grawerowana, proj. Henryk Grunwald, 1945-55, wł. prywatna. Fot. udostępniona

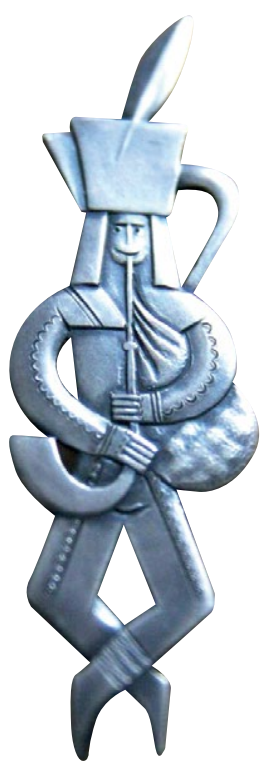

14. Broszko-wisior Tańczący dudziarz,

blacha srebrna wycinana, kuta, wytłaczana, grawerowana, proj. Henryk Grunwald, ok. 1948 r., wł. prywatna. Fot. udostępniona
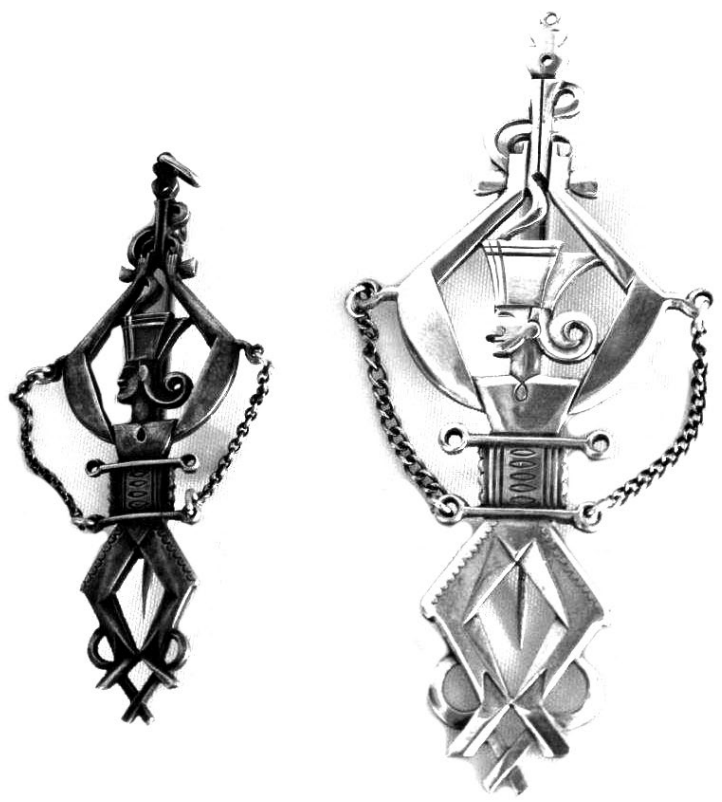

13. Broszko-wisior Tańczący zbójnik - dwie wersje wymiarowe, blacha srebrna wycinana, kuta, grawerowana, proj. Henryk Grunwald, 1945-1955, wł. prywatna. Fot. udostępniona

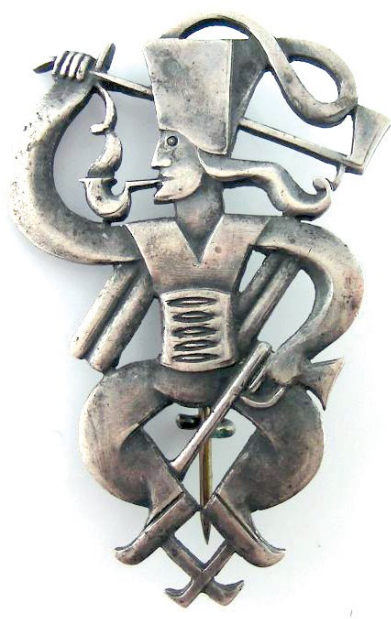

15. Broszko-wisior Zbójnik z ciupagą, blacha srebrna wycinana, kuta, grawerowana, proj. Henryk Grunwald, 1945-1955. Fot. z archiwum sklepu OldLifeStyle Pawła Łuca 


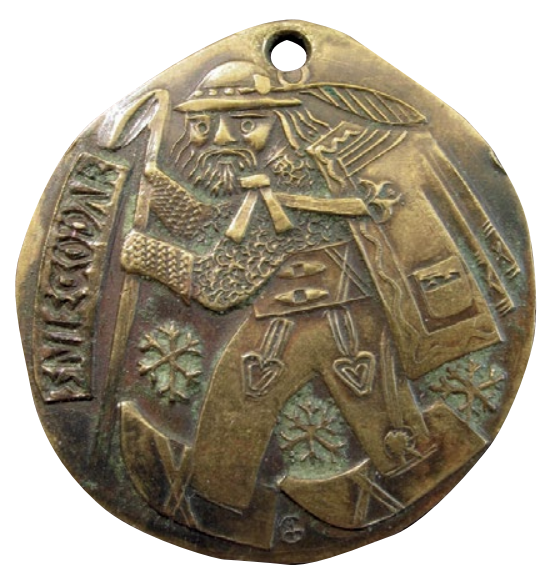

16. Wisior-medal Śniegodar, mosiądz, odlew cyzelowany, Andrzej Gałek, 1945-1949; wł. prywatna. Fot. udostępniona

z kilkoma sprzączkami, koszule z szerokimi rękawami, osadzony na głowie kłobuk, w ich rękach zaś widnieją „zbójnickie” atrybuty - pistolety, ciupaga, dudy, a w ustach fajka (il. 12, 13, 14, 15). Wisiory przypominające spinki można zatem uznać za bezpośrednio nawiązujące do kultury podhalańskiej, ale takiej genezy z pewnością nie można doszukiwać się w przedstawieniach zbójników, chyba że jako ich inspiracja ikonograficzna wskazane zostaną np. liczne, często anonimowe ludowe malowidła na szkle, zawierające podobne wizerunki. Równie ciekawą drogę inspiracji ikonograficznej dostrzec można w medalu-zawieszce autorstwa Andrzeja Gałka (nb. urodzonego w Zakopanem), na którym przedstawił on ubranego w strój regionalny starego górala, opatrzonego imieniem „Śniegodar” (na odwrociu wybita została nazwa „Zakopane")" O ile sam typ takiego wizerunku uznać można za ugruntowany w polskiej sztuce już od XIX wieku, to już opatrzenie go imieniem o pseudosłowiańskim brzmieniu pozwala doszukiwać się tu dalekiego echa interpretacji sztuki podhalańskiej jako narodowej, a nawet rodzimej (il. 16).

Wydaje się, że realizowane później dzieła biżuterii nawiązujące do szeroko pojętej kultury Podhala z pewnością miały znacznie mniejszy zasięg ilościowy

11 A. Kasprzak-Miler, A. Frąckiewicz, dz. cyt., poz. 31.

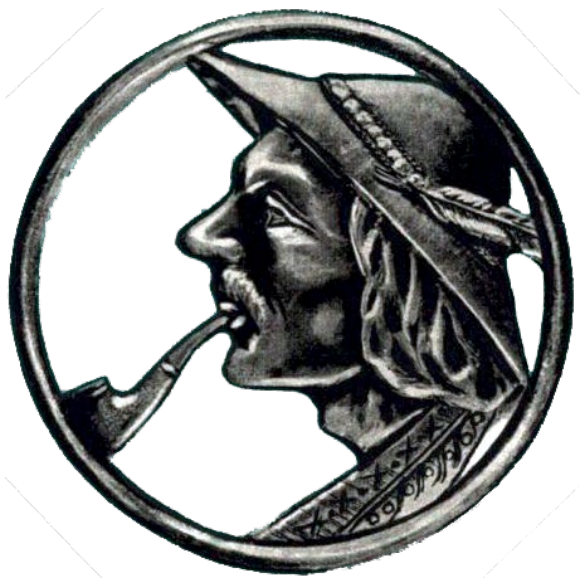

17. Broszka z wizerunkiem górala, srebro wycinane, wytłaczane, wyk. spółdzielnia Rytosztuka, Poznań, przed 1957. Fot. wg: Katalog wyrobów jubilerskich 1957, Warszawa 1957, s. 23

w zakresie przedstawianych wzorów. Pozwalają to stwierdzić dwa katalogi biżuterii, przygotowane przez Centralny Zarząd Przemysłu i Handlu Jubilerskiego (nast. Centrala Jubilerska „Jubiler”) - pierwszy z 1957, a drugi z $1966 \mathrm{r}^{12} \mathrm{~W}$ pierwszym z katalogów widnieje wyłącznie jedno przedstawienie wisiora z góralskim zbójnikiem (autorstwa Henryka Grunwalda), co pozwala zresztą sądzić, że przynajmniej do tego roku był on w ciągłej ofercie „Jubilera”. Obok wisiora widnieje wyobrażenie produkowanej przez spółdzielnię Rytosztuka broszki, zawierającej w ramce profilowy wizerunek górala z fajką (il. 17). Przedstawienie to odznacza się na tyle schematycznym ujęciem, że trudno jednoznacznie wskazać jego ewentualny pierwowzór lub uznać je za wzór w pełni oryginalny, np. opracowany przez Danutę Sokolnicką. Jednak znacznie bardziej frapujący jest fakt, że broszkę tę wytwarzano masowo w Poznaniu, który bynajmniej na Podhalu nie leży; zapewne była ona traktowana jako wyrób tzw. pamiątkarstwa, a geneza jej projektu być może związana jest z drzeworytami Władysława Skoczylasa. Na odwołania do twórczości tego artysty wskazuje z pewnością inne dzieło - broszka

12 Katalog wyrobów jubilerskich 1957, Warszawa 1957; W. Malicki, Wzornik wyrobów jubilerskich, Warszawa 1966. 


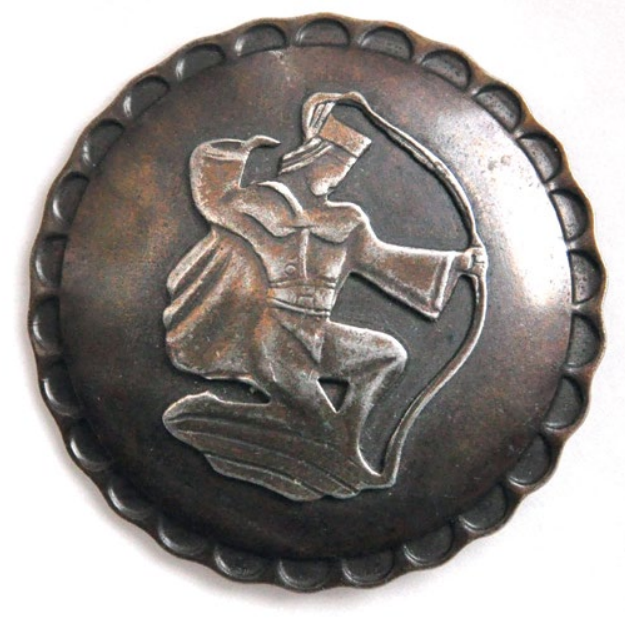

18. Broszka z przedstawieniem góralskiego łucznika, blacha cynkowa miedziowana, wycinana, wytłaczana; lata 40.-50. XX w., wł. prywatna. Fot. udostępniona

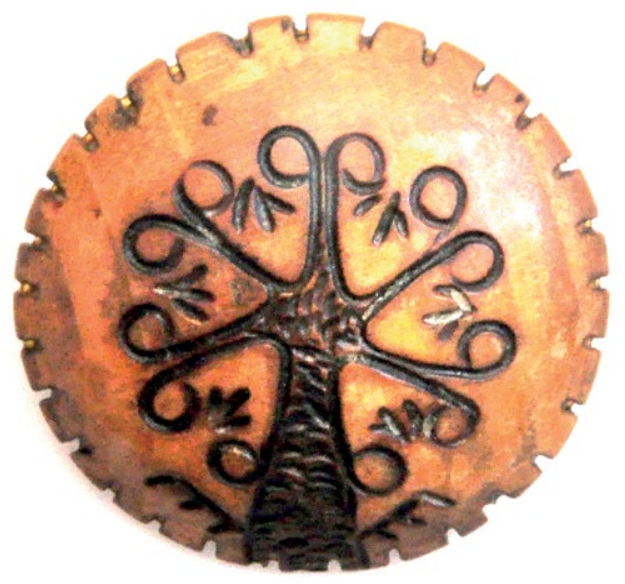

20. Broszka z motywem góralskiej parzenicy, drewno toczone, wypalane, Zakopane (?), lata 70. XX w., wł. prywatna. Fot. udostępniona

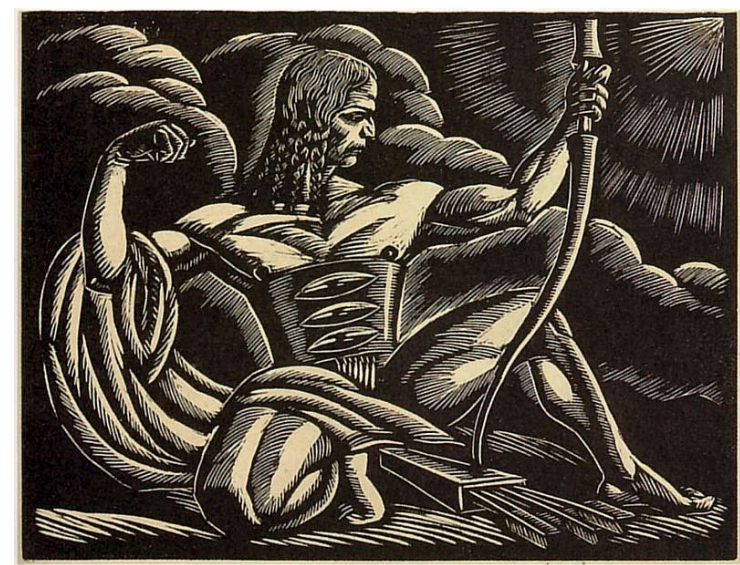

19. Drzeworyt Łucznik (Apollo), Władysław Skoczylas, 1923. Fot. wg: https://en.wikipedia.org/ wiki/Władysław_Skoczylas\#/media/File:SkoczylasŁucznik.jpg [dostęp $20 \mathrm{X}$ 2020]

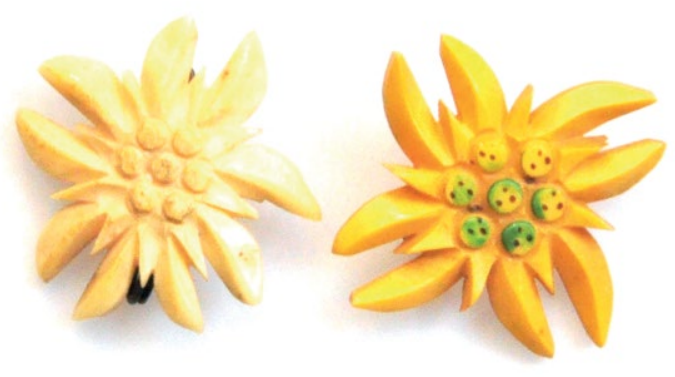

21. Broszki w formie kwiatu szarotki, kość bydlęca oraz galalit, wycinanie oraz odlewanie i wycinanie, lata 50.-60. XX w., wł. prywatna. Fot. udostępniona z wizerunkiem górala napinającego łuk, dla której oczywistym pierwowzorem była grafika z 1923 r., przedstawiająca przyklękającego na jedno kolano i strzelającego z łuku Apolla (znana także jako Łucznik), wyobrażonego pod postacią górala $\mathrm{z}$ charakterystycznym, szerokim pasem i z włosami zaplecionymi w popularne do XIX w. warkoczyki (il. 18, 19) ${ }^{13}$. Pomimo wskazania pierwowzoru przedstawienia nie można

13 Ilustracja za: https://zbc.uz.zgora.pl/dlibra/show-content/ publication/edition/6291?id=6291 [dostęp 20 X 2020]. jednak bezsprzecznie określić czasu i miejsca powstania tej broszki, choć w najnowszej literaturze określa się ją jako powstałą w latach 40.-50. XX w. ${ }^{14}$

Nieliczne przykłady biżuterii tworzonej w spółdzielniach, a właściwie galanterii przetworzonej na biżuterię odwołującą się bezpośrednio do wzornictwa stylu zakopiańskiego rozumianego jako zbiór niezmiennych i tradycyjnych zasad, form

14 Hand Made. Polska sztuka srebra lat 1945-1979, red. K. Nowakowska, Legnica 2020, s. 48-49. 
22. Wisior w formie chusty góralskiej, srebro odlewane, kute, drut i milgryf wyginane, turkus, proj. Andrzej Folfas, wyk. spółdzielnia Imago Artis; Kraków, 1986, wł. prywatna. Fot. udostępniona

i wzorów, pozwalają przedstawić oczywisty wniosek, że tego rodzaju produkcja nie była prowadzona w sposób szczególnie masowy i miała przede wszystkim charakter regionalnego pamiątkarstwa. Uzupełniały ją liczniejsze dzieła, które nie wpisując się w styl zakopiański, jedynie nawiązywały swoim kształtem lub ikonografią do kultury materialnej i duchowej Podhala. Produkcja tego rodzaju, obejmująca np. nieskomplikowane technologicznie drewniane broszki z wypalanymi motywami parzenic lub galalitowe albo kościane przedstawienia kwiatu szarotki (il. 20, 21), prowadzona była w warunkach półlegalnych i niekontrolowanych przez instytucje państwowe i z tego powodu ma ona charakter anonimowy. Natomiast szczególną i odrębną grupę stanowiły dzieła wysokiej klasy, np. srebrne wisiory i broszko-wisiory Henryka Grunwalda oraz broszki z Rytosztuki - produkowane w Warszawie i w Poznaniu, a zatem w miastach dość odległych od Zakopanego. Wypełniały one jednak zapotrzebowanie rynku na przedmioty pełniące przede wszystkim rolę ekskluzywnych pamiątek, często eksportowanych z Polski, głównie do USA. Z kolei analiza innych dzieł biżuterii, np. powstającej w latach 70. i 80. XX wieku serii wisiorów Imago Artis (il. 22), które można interpretować jako odwzorowanie formy i zdobień wzorzystych chust kobiecych na Podhalu, wkracza jednak w obszar zaledwie analogii kształtu, a nie istniejących związków genetycznych pomiędzy takimi przedmiotami ${ }^{15}$. Tym samym oznacza to wejście w obszar zupełnie odrębnych badań, dotyczących zjawiska tzw. etno-dizajnu.

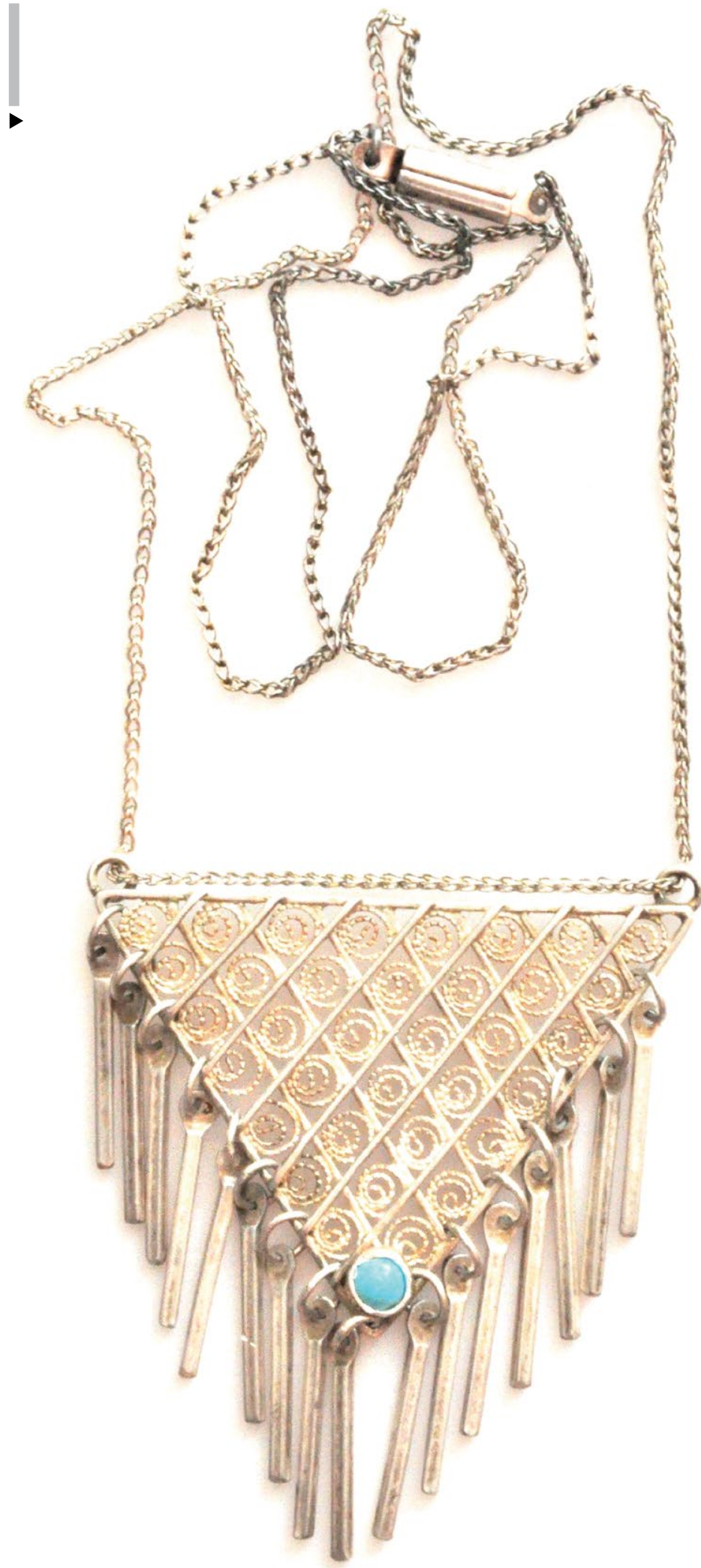

15 A. Domańska, Góralski etnodizajn, czyli sztuka ludowa Podhala jako źródło inspiracji we współczesnym wzornictwie, Gdańsk 2019. 
STRESZCZENIE

INSPIRACJE SZTUKĄ I KULTURA PODHALA W POWOJENNEJ GALANTERII I BIŻUTERII POLSKIEJ

Zainteresowanie sztuką ludową Podhala wśród polskich artystów i badaczy sięga lat osiemdziesiątych XIX wieku. Wynikało ono z dostrzeżenia artystycznej wartości tworzonych tam dzieł oraz poszukiwań tzw. sztuki narodowej i rodzimej, tak bardzo ważnych dla polskiej kultury i tożsamości. Inspiracje kulturą materialną i artystyczną Podhala przyczyniły się m.in. do wielkiego sukcesu polskiej ekspozycji na Wystawie Sztuki Dekoracyjnej w Paryżu w 1925 roku. Zainteresowanie to nie zmniejszyło się po 1945 r., ale przybrało inne formy. W tym czasie powstawały w Polsce liczne spółdzielnie, których zadaniem było tworzenie przedmiotów codziennego użytku i dzieł sztuki ludowej, zgodnie z lokalną tradycją rękodzielniczą, ikonograficzną, zdobniczą itp. Pewną część produkcji stanowiła tzw. metaloplastyka - sprzączki do pasków, spinki do koszul, zatrzaski do torebek, noże, okucia fajek i in., których forma była inspiracją dla artystów tworzących dzieła biżuterii - bransoletki, broszki, wisiory itp. Asortyment ten uzupełniony został także o inne elementy - wykonywane z blachy, kości bydlęcej, galalitu i drewna broszki, wisiorki i breloki, które były przede wszystkim pamiątkami przywożonymi $\mathrm{z}$ tego bardzo popularnego regionu turystycznego.

\section{SŁOWA KLUCZOWE}

biżuteria polska po 1945, wzornictwo biżuterii XX w., sztuka podhalańska, Podhale, Zakopane

\section{SUMMARY}

\section{ART AND CULTURE OF THE PODHALE REGION AS AN INSPIRATION IN THE POSTWAR POLISH JEWELLERY AND ACCESSORIES}

The interest in the folk art of the Podhale region among Polish artists and researchers dates back to the 1880 s. It resulted from the perception of the artistic value of the works created here, as well as the search for the so-called national and native art, very important for Polish culture and national identity. Inspiration with the material culture of Podhale came from, among others a great effect in the form of the success of Polish art at the Exhibition of Decorative Art in Paris in 1925.

This interest did not diminish after 1945 , but took other forms. At that time, numerous cooperatives were established in Poland, whose task was to create everyday objects and works of folk art, in line with the local tradition in terms of technology, iconography, ornaments, etc. In Podhale, among many produced works, a certain part was the so-called metalwork - belt buckles, shirt clips, purse fasteners, knives, etc., the shape of which was an inspiration for artists creating bracelets, brooches, pendants, etc. This assortment was supplemented with other items - made of sheet metal, bovine bone, galalite and wood, brooches, pendants, and key rings, which were primarily souvenirs brought from this very popular tourist region.

\section{KEYWORDS}

Polish jewellery (after 1945), jewellery design of the zoth century, highlanders art, Tatra mountain region, Zakopane 


\section{BIBLIOGRAFIA}

Domańska Agnieszka, Góralski etnodizajn czyli sztuka ludowa Podhala jako źródło inspiracji we współczesnym wzornictwie, Gdańsk 2019.

Gmurczyk Roman, Organizacja cepeliowska w latach 1949-2014. Fakty i ludzie. Warszawa 2014.

Gradowski Michał, Dawne złotnictwo. Technika i terminologia, Warszawa 1984.

Hand Made. Polska sztuka srebra lat 19451979, red. Krystyna Nowakowska, Legnica 2020.

Hübner-Wojciechowska Joanna, Sztuka Skalnego Podhala. Przewodnik dla kolekcjonerów, Warszawa 2019.

Huml Irena, Warsztaty Krakowskie, Wrocław-Warszawa-KrakówGdańsk 1973 (reedycja tekstu: Dziedzic Maria, Huml Irena, Myczkowska Anna, Pleciak Agata, Szwaja Anna, Warsztaty Krakowskie 1913-1926, Kraków 2009).

Kasprzak-Miler Agnieszka, Frąckiewicz Anna,Polska biżuteria artystyczna z lat 1945-1950 ze zbiorów Muzeum Narodowego w Warszawie, Warszawa 1999.

Kasprzak-Miler Agnieszka, Wpływ Biura Nadzoru Estetyki Produkcji na kształt polskiej biżuterii artystycznej, w: W kręgu sztuki przedmiotu. Studia ofiarowane Profesor Irenie Huml przez przyjaciół, kolegów i uczniów, red. Maria Dłutek, współpr. Anna Kostrzyńska-Miłosz, Warszawa 2011, s. 255-264.

Katalog wyrobów jubilerskich 1957, Warszawa 1957.

Korduba Piotr, Ludowość na sprzedaż. Towarzystwo Popierania Przemysłu Ludowego, Cepelia, Instytut Wzornictwa Przemysłowego, Kraków 2013.

Listy o stylu zakopiańskim 1892-1912. Wokół Stanisława Witkiewicza, opr. Maria Olszaniecka i Anna Micińska, wstęp, kom., opr. Michał Jagiełło, Kraków 1979.

Matlakowski Władysław, Zdobienie i sprzęt ludu polskiego na Podhalu. Zarysy życia ludowego, Warszawa 1901.

Nowakowska Krystyna, Henryk Grunwald. Mistrz kompozycji w metalu, Legnica 1998.

Witkiewicz Stanisław, Styl zakopiański, w: Sztuka i krytyka u nas (1884-1898), Lwów - Warszawa - Poznań 1899, s. 619-667.

Wystawa paryska 1925. Materiały z sesji naukowej Instytutu Sztuki PAN, Warszawa 16-17 listopada 2005 roku, red. Joanna Sosnowska, Warszawa 2007.

Wzornik wyrobów jubilerskich, opr. Wojciech Malicki, Warszawa 1966. 